\title{
MORPHOMETRIC ANALYSIS USING GEO-INFORMATION TECHNIQUES FOR DIFFERENT WATERSHEDS IN NORTHEASTERN PART OF ERBIL CITY, KURDISTAN REGION, NORTH IRAQ
}

\author{
${ }^{1}$ Kaiwan Fatah ${ }^{*}$ 'Shwan Seeyan and ${ }^{3}$ Shevan Jirjees \\ ${ }^{1}$ Department of Geology, College of Science, Salahaddin University, Erbil, Iraq \\ ${ }^{2}$ Soil and Water Department, Engineering Agriculture Science College, Salahaddin University, Erbil, Iraq \\ ${ }^{3}$ Department of Geology, College of Science, Salahaddin University, Erbil, Iraq \\ *E-mail: kaiwan.fatah@su.edu.krd \\ Received: 22 March 2020; accepted: 27 May 2020
}

\begin{abstract}
The present research attempts to study detail morphometric analysis of Harrir and Shaqlawa watersheds in the northeastern part of Erbil city, north of Iraq. The areas of the watersheds are $350 \mathrm{Km}^{2}$ and $223 \mathrm{Km}^{2}$ for Harrir and Shaqlawa, respectively. To achieve the aims of this study, the ALOS PALSAR Digital Elevation Model data, and Geo-information (Remote sensing and GIS) techniques were used for determining and analyzing morphometric parameters in terms linear, aerial and relief aspects. Several tools in ArcGIS 10.4 software were utilized for preparing and producing maps, analyzing and assessing various characteristics of the parameters. The main results show that there is a strong inverse relationship between stream order, number and length of the stream in the watersheds of the study area by $R^{2}$ values $\left(R^{2}=0.78\right.$ and 0.81 of Harrir watershed and $R^{2}=$ 0.8 and 0.79 for Shaqlawa watershed, respectively). The watersheds are elongated in shape with dendritic, sub dendritic to parallel drainage patterns. Moreover, detail morphometric analysis shows that the watersheds have a low runoff, low permeable material, and moderate slope. The structural geology and climatic parameters of the study area have influenced the landform development and stream behavior in the watersheds. Hence, the present study is useful and essential for watershed management and planning rainfall harvesting.
\end{abstract}

Keywords: Morphometric parameters; Remote sensing; ALOS PALSAR DEM; GIS application; Kurdistan region

\section{INTRODUCTION}

Morphometric analysis is the most crucial technique used in studying the mathematical relations between drainage characteristics and it is utilized to map and compare drainage 
networks and to realize the factors that influence on forming various systems of drainage patterns (Ali and Khan, 2013; Sakthivel et al., 2019). Watersheds can be managed and described in terms of their physical features of watersheds by morphometric analysis, and it plays an important role for many studies, such as in environmental studies, soil erosion, water harvesting, impact of geology factors on the causing various streams systems, and land cover land use planning (Aravinda and Balakrishna, 2013; Arabameri et al., 2018). In recent decades, remote sensing is integrated with the geographic information system (GIS) techniques which are used successfully for investigating morphometric parameters of watersheds by several studies. Aziz et al., 2020 mentioned that the derivation of data (flow direction, flow accumulation, basin, and sub-basins), in addition to the morphometric parameters using GIS, would be very valuable in water harvesting site selection with minimum cost and time compared to the traditional methods; moreover, it is giving acceptable results. Al-Qayim and Ahmed (2015) have studied geomorphological of Dewana drainage watershed by using Geoformation techniques with regards to Digital Elevation Model (DEM), Satellite images, geological, topographic, and structural maps. Moreover, remote sensing and GIS methods have been applied for analyzing the morphometric parameters of the subcatchments of Sukri River, Rajasthan, India. The Landsat ETM+ and Digital elevation data were utilized to assess the parameters (Kumar, 2013). Al-Saedi and Al-Obaidi (2018) have used GIS techniques integrated with remote sensing data (30 m resolution DEM) for the morphometric investigation of the Euphrates River Basin in Iraq. Therefore, for this study, remote sensing and GIS techniques have been used for analyzing the morphometric parameters and management of two major watersheds in the Kurdistan Region. The main goals of this study are to calculate the morphometric parameters of the watersheds, comprehend the geological, hydrological and geomorphological characteristics of the watersheds, comparing between the watershed's drainage pattern, stream behavior, and morphometric location of the drainage within the network helping for watershed management. Also, observing the role of remote sensing and GIS techniques in mapping and extracting the drainage network of the watersheds.

\section{STUDY AREA DESCRIPTION}

The study area is located in the northeastern part of Iraq. The watersheds lie approximately 50 $\mathrm{km}$ to the northeast of the Erbil City capital of the Kurdistan Region of Iraq. The catchment areas of the watersheds are about $573 \mathrm{~km}^{2}$ setting between latitude $\left(36^{\circ} 18^{\prime} 30^{\prime \prime} \mathrm{N}-36^{\circ} 38^{\prime}\right.$ $\left.30^{\prime \prime} \mathrm{N}\right)$ and longitude $\left(44^{\circ} 7^{\prime} 00^{\prime \prime} \mathrm{E}-44^{\circ} 31^{\prime} 30^{\prime \prime} \mathrm{E}\right)$ with elevation ranges from 383 to 1970 
$\mathrm{m}$ above sea level, which is bounded from the northeast by Harir Anticline and from the southwest by Safin Anticline (Fig. 1). The watersheds flow to the Great Zab River, the average annual rainfall and temperature of the study area is about $684.2 \mathrm{~mm}$ and $21.4{ }^{\circ} \mathrm{C}$ in the three last decades.

The geology of the area is characterized by sedimentary rocks, and the exposed formations in the study area are range from the Upper Cretaceous to Quaternary Period with various lithology including clastic and carbonate rocks (Qamchuqa, Bekhme, Shiranish, Zanjero, Kolosh, Sinjar, Khurmala, Gercus, Avanah, Pila Spi, Fatha, Injana formations and Quaternary sediments) (Sissakian and Fouad, 2014; Seeyan and Merkel, 2015; Omar and Syan, 2017). Structural geology of the area has a significant role to understanding and controlling distribution of the drainage pattern because Harir and Safin anticlines which are major folds in the study area have been influenced by incidence strike slip-faults and highly jointed of carbonate formations in the area (Zebari and Burberry, 2015; Omar and Syan, 2017).



Fig. 1. Location map of the watersheds and hill shade of the study area

\section{MATERIALS AND METHODS}

Advanced Land Observing Satellite DEM (ALOS PALSAR DEM) with $12.5 \mathrm{~m}$ resolution was used for this study, which was downloaded from the Alaska Satellite Facility, Topographical map at the scale of 1:25,000, geological map at the scale of 1:250,000, and satellite imagery for drainage pattern extraction and morphometric analysis. The GIS 
technique was utilized to map drainage networks and analyze the important morphometric parameters to investigate of the key tributaries of the selected area. The work steps are shown in the below flowchart diagram (Fig. 2).

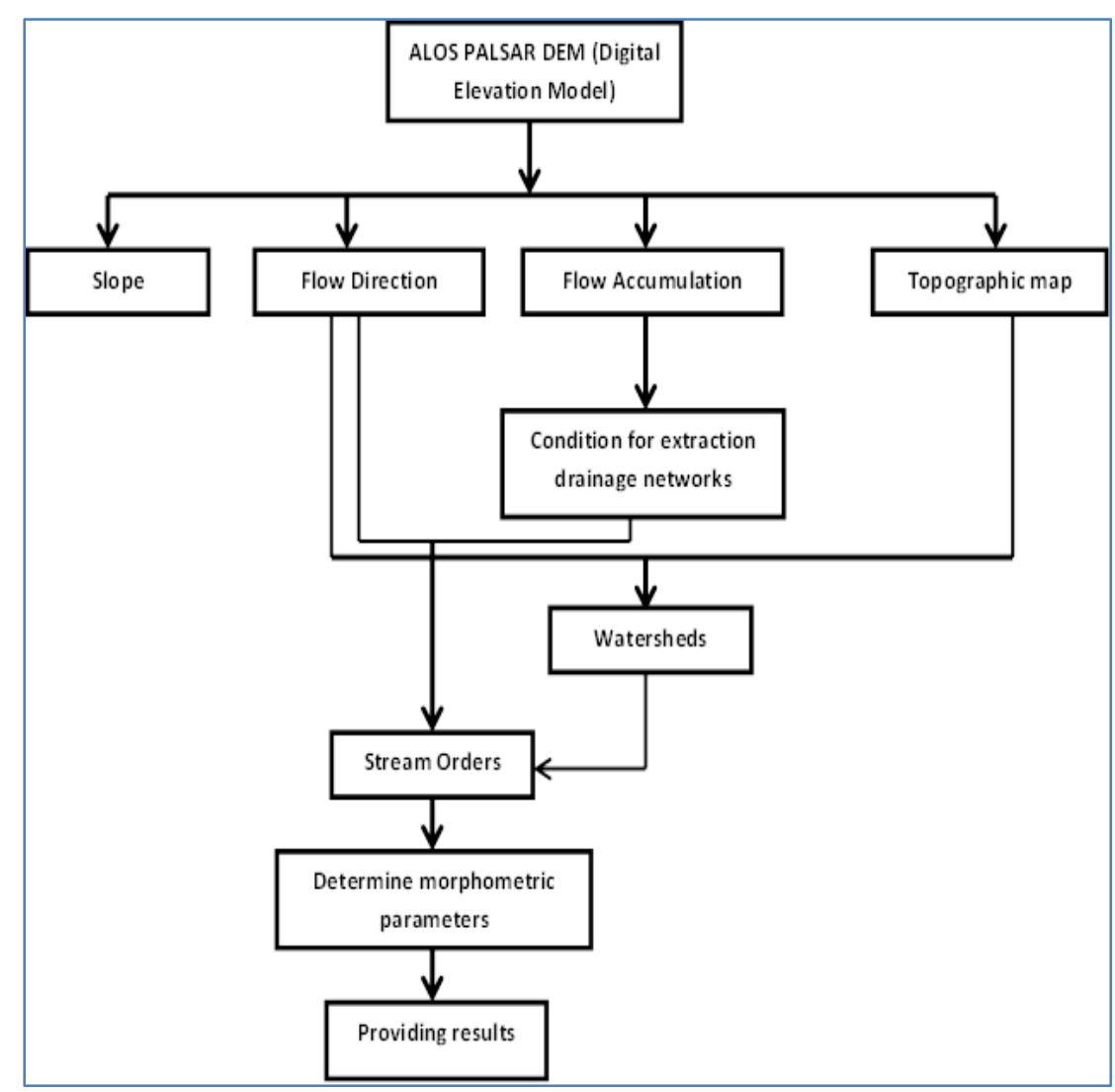

Fig. 2. Flow diagram shows the steps of methods and data investigation

\section{Morphometric Parameters}

The morphometric parameters have been divided into three types include linear, areal and relief aspects.

\section{Linear aspects}

Linear aspects comprise several parameters, which are the measurements of linear characteristics of the drainage; for example, basin length, stream order, perimeter, stream number, stream length, mean stream length, stream length ratio and bifurcation ratio are debated below:

1. Basin length (Lb)

The geometric measurement of form and extent of the drainage watershed is known as basin length. It is the maximum length of the watershed within the maximum circle around the boundary of the basin, which is parallel to the main-stream (Rawat et al., 2017). 
2. Perimeter $(\mathrm{P})$

Perimeter is the length of the stream watershed border (Rawat et al., 2017).

3. Stream order

The description of stream orders is the initial stage of the drainage watershed analysis. Horton (1945) firstly presented the subsequent system into the United State, and it has marginally improved by Strahler (1964). It is also stated that the hierarchal connection between the sections of the separate streams that assemblies a drainage system. Ranking of the streams at the study area has been carried out based on the method proposed by Strahler (1964). The first-order stream is the smallest sensitive branches, which has not sub-tributaries, linking two first-orders streams are designed to second-order stream, the third-order is formed by connection two second-orders and so on/forth (Ali and Khan, 2013).

4. Stream number $(\mathrm{Nu})$

Stream number is a number of branches of dissimilar stream segments in an assumed drainage watershed tends sensibly to estimate a converse geometric ratio by Horton (Horton, 1932 in Ali and Khan, 2013). It has been stated that there is an inverse relationship between stream order and stream number.

5. Stream length $(\mathrm{Lu})$

Stream length is the length of each stream order in a drainage watershed that can be measured by ArcGIS software based on the law stream length which proposed by Horton (1945). The total length of each stream segment is the summation of lengths of all stream of a certain order.

6. Mean stream length (MLu)

The average stream length can be obtained from dividing the total length of streams of a certain order to the total number of stream orders in the watershed. It is stated that the mean stream length has a direct relationship with stream order, with an increasing stream segment, the total mean length of the streams increases (Aravinda and Balakrishna, 2013). The mean stream length calculated by the equation below:

$$
M L \mathrm{u}=\frac{\sum_{i=1}^{N} \mathrm{Lu}}{N u}
$$

Where MLu is mean stream length, $\mathrm{Lu}$ is total length of stream order, and $\mathrm{Nu}$ is total number of stream orders.

7. Stream length ratio (RLu) 
The stream length ratio is a ratio of dividing the total length of the stream order $(\mathrm{Lu})$ to the total length of streams of its next lower order (Horton, 1932 in Ali and Khan, 2013). Accordingly, the formula below used to measure stream length ratio:

$$
\mathrm{RLu}=\mathrm{Lu} / \mathrm{Lu}-1
$$

Where $\mathrm{RLu}$ is stream length ratio, $\mathrm{Lu}$ is total length of the stream order, and Lu-1 is total length of streams of its next lower order.

\section{Bifurcation ratio $(\mathrm{Rb})$}

The ratio of the stream number segments of a particular order to the number of segments of the next higher order is called the bifurcation ratio. It has been considered as an index of relief and separations (Schumm, 1956 in Ali and Khan, 2013). In general, the bifurcation ratio is a significant and dimensionless parameter and it ranges from 3 to 5 . There might be a difference in bifurcation ratio of each order with its next order, the geological and lithological development of stream watershed causes and attributes these irregularities (Pareta and Pareta, 2011).

\section{Areal aspects}

There are various drainage parameters which belong to areal aspects such as Area, stream frequency, drainage density, drainage texture, elongation ratio, circularity ratio, constant of channel maintenance and length of overland flow, they are debated below:

1. Basin area (A)

The watershed area is the area which locates inside the boundary of the basin.

2. Stream frequency $(\mathrm{S} f)$

The stream frequency is defined as the ratio between the total stream number of the watershed and the watershed area, and the ratio was presented firstly by Horton (1945). Precipitation is the main important parameter for controlling this ratio. The higher values of the stream frequency indicate high resistance of surface and sub-surface rocks, lithology with low permeability, higher relief, and sparse vegetation cover, while lower values of the stream frequency are characteristics of low resistance, low permeable lithology of surface and subsurface material, and low relief (Kumar, 2013). The stream frequency calculated by the formula below:

$$
S f=\frac{\sum_{i=1}^{N} N u}{A}
$$

Where $\sum_{i=1}^{N} N u$ is total stream number of the watershed, A is a watershed area and $\mathrm{S} f$ is Stream frequency. 


\section{Drainage density $(\mathrm{D} d)$}

The drainage density is an important quantitative parameter for showing the development of the watershed due to the impacts of climate, geology, structure, and relief of the area, and landscape form controlled by those variables which show the drainage density ratio. The drainage density is computed by dividing the total length of streams of all orders to the total watershed area (Horton 1932; Pareta and Pareta, 2011) as below:

$$
D d=\frac{\sum_{i=1}^{N} L u}{A}
$$

Where: $\sum_{i=1}^{N} L u$ is total streams length of all orders, A is watershed area and $\mathrm{D} d$ is Drainage density $\left(\mathrm{km} / \mathrm{km}^{2}\right)$.

The high drainage density value indicates permeable subsurface lithology, lower relief, and denser vegetation cover area, while low value represents lower permeable or weak subsurface lithology, higher relief, and spare vegetation cover area (Rawat et al., 2017).

4. Drainage texture $(\mathrm{D} t)$

The drainage texture is one of the significant factors in the morphometric investigation, which means the comparative spacing of drainage lines, and those used for comparing permeable and impermeable material. The drainage texture can be defined as dividing the total stream number of all orders by the perimeter of the basin (Horton, 1932 in Ali and Khan, 2013). The drainage texture has been classified into five textures; less than 2 represents a very coarse, the course is shown by values from 2 to 4 , a value between 4 and 6 show moderate, fine represents values from 6 to 8 , and a value greater than 8 indicates very fine drainage texture (Rawat et al., 2017).

5. Elongation ratio $(\mathrm{Re})$

It is the ratio between the diameter of the circle having the same extent as of the watershed and to the maximum length of the watershed (Schumm, 1956; Kumar, 2013). The lower value of the elongation ratio indicates an elongated basin, whereas circular or no elongated basin is shown by the high value of elongation ratio (Pareta and Pareta, 2011). The elongation ratio is calculated by the formula below:

$$
\mathrm{RE}=1.128 \sqrt{\mathrm{A}} / \mathrm{Lb}
$$

Where $\mathrm{RE}$ is elongation ratio, $\mathrm{A}$ is an area of the basin, and $\mathrm{Lb}$ is the maximum length in the basin.

6. Circularity ratio $(\mathrm{Rc})$

The circularity ratio is defined as the ratio of basin area to the extent of the circle having the same perimeter as the basin (Miller, 1953; Ali and Khan, 2013). The circularity ratio is a 
dimensionless parameter that is used as a quantitative technique for measuring and determining the shape of the watershed and varies from zero for elongated basin and up to one for the spherical watershed (Veeranna et al., 2017). The circularity ratio calculated by the formula below:

$$
R C=\frac{4 \pi A}{P^{2}}
$$

Where $\mathrm{Rc}$ is the circularity ratio, $\mathrm{A}$ is the basin area, and $\mathrm{P}$ is the perimeter of the basin.

7. Form factor (Ff)

The form factor is defined as dividing the area of watershed by square of maximum length of the watershed, and the shape of the watershed can be determined by the equation below (Aravinda and Balakrishna, 2013). The form factor calculated by the formula below:

$$
\mathrm{Ff}=\mathrm{A} / \mathrm{Lb}^{2}
$$

Where form factor is symbolized by Rf, watershed area is labeled by A, and Lb is the length of watershed.

8. Constant of channel maintenance $(\mathrm{C})$

The constant of channel maintenance is defined as an inverse of drainage density, and can be calculated by the equation below (Kumar, 2013). The constant indicates the number of $\mathrm{km}^{2}$ of watershed surface requisite to improve and sustain a stream of one $\mathrm{km}$ long (Veeranna et al., 2017). The constant of channel maintenance calculated by the formula below:

$$
\mathrm{C}=1 / \mathrm{Dd}
$$

Where $\mathrm{C}$ is constant of channel maintenance and $\mathrm{Dd}$ is drainage density.

9. Length of overland flow $(\mathrm{Lg})$

The length of overland flow was defined by Horton (1945) as a length of rainfall water run on the earth's surface before it is merged into definite channels (Pareta and Pareta, 2011). The hydrologic and physiographic evolution of drainage watersheds has been influenced by a significant independent parameter, which is the length of overland flow (Ali and Khan, 2013). The length of overland flow calculated by the equation below:

$$
\mathrm{Lg}=1 / 2 \mathrm{Dd}
$$

Where $\mathrm{Lg}$ is the length of overland flow and Dd is drainage density.

\section{Relief aspects}

There are various important parameters in the morphometric analysis which belong to relief aspects. They are used for understanding the development and denudation of the watershed, and the water flow direction can be detected by those factors such as; basin relief, relief ratio, dissection index, watershed slope and ruggedness number. 
1. Basin relief $(\mathrm{Rb})$

The basin relief is the difference between the maximum and minimum altitudes within the watershed (Rawat et al., 2017). The elevation values have been obtained from DEM of the area with $12.5 \mathrm{~m}$ resolution; following the equation shown below:

$$
\mathrm{Rb}=\mathrm{H}-\mathrm{h}
$$

Where $\mathrm{Rb}$ is base basin relief, $\mathrm{H}$ is the maximum elevation in basin and $\mathrm{h}$ is minimum elevation in the basin.

2. Relief ratio $(\mathrm{Rr})$

The relief ratio was termed as the ratio of total watershed relief divided by the maximum watershed length determined adjacent to the main stream line (Schumm, 1956; Pareta and Pareta, 2011). The high value of relief is due to steep slope and high relief basin, whereas low value indicates hard rock and gentle slope (Veeranna et al., 2017). Relief Ratio calculated by the equation below:

$$
\mathrm{Rr}=\mathrm{Rb} / \mathrm{Lb}
$$

Where $\mathrm{Rr}$ is relief ratio, $\mathrm{Rb}$ is relief of watershed and $\mathrm{Lb}$ is basin length.

3. Dissection index (Di)

The dissection index is a factor indicating degree dissection or vertical erosion and explains the evolution of terrains in any given basin (Rawat et al., 2017). The value of dissection index ranges from 0 to1. The low value near zero indicates a complete absence of vertical erosion and dissection because the area is a flat surface, however, accordance with vertical cliffs, ridge, hill slope or seashore is represented by high value of dissection index near 1 . The high value of the index is due to an improved amount of erosion (Pareta and Pareta, 2011). The dissection index calculated according to the formula below:

$$
\mathrm{Di}=\mathrm{Rb} / \mathrm{aRb}
$$

Where $\mathrm{Di}$ is dissection index, $\mathrm{Rb}$ is basin relief, and $\mathrm{aRb}$ is absolute basin relief.

\section{Ruggedness Number (Rn)}

It is a product of multiplying drainage density to the relief of the watershed. This is an important parameter that is used for high gradient and the slope of the drainage system and to determine the vulnerability of watershed to soil erosion (Aravinda and Balakrishna, 2013). The low value of ruggedness means the watershed is less vulnerable to soil erosion and more influenced by structural geology, while high ruggedness value indicates watershed prone to soil erosion which related to increasing relief and drainage density of the area (Rawat et al., 2017). It can be calculated by the equation below:

$$
\mathrm{Rn}=\mathrm{Rb} \times \mathrm{Dd}
$$


Where ruggedness number is symbolized as $\mathrm{Rn}, \mathrm{Rb}$ represents watershed relief and drainage density is labeled as Dd.

\section{RESULTS AND DISCUSSION}

The basin length of the Harrir and Shaqlawa watersheds are $36.6 \mathrm{~km}$ and $28.3 \mathrm{~km}$, respectively, the perimeters are $111.5 \mathrm{~km}$ and $105.1 \mathrm{~km}$, respectively. The stream order of the Harrir and Shaqlawa watersheds is seventh-order and sixth-order, respectively (Table 1 and Fig. 3). Total streams number of the Harrir and Shaqlawa watersheds are 9019 and 5790 , respectively. Generally, there is an inverse relationship between total stream length and stream orders, with increasing stream order the total length of streams decreases and vice versa. The stream length of the watersheds in the study area is shown in (Table 1). The stream length ratio of Harrir watershed ranges between 0.35 and 0.73 for $1^{\text {st }}$ stream order, and the ranges of stream length ratio of Shaqlawa watershed ranges from 0.29 for the $4^{\text {th }}$ stream order to 4.3 for $1^{\text {st }}$ stream order. The small value of the bifurcation ratio indicates that the drainage network of a region is less or not impacted by geological and structural disturbances. The drainage segments of the watershed have been controlled by the structural and geological effects which are shown by the higher value of bifurcation ratio. Values of bifurcation ration of Harrir watershed vary from 1.1 to 225 and for Shaqlawa watershed ranges from 2.17 to 41 , and the mean bifurcation ratio is 39.095 and 10.788 for the two watersheds, respectively. This high value of the bifurcation ratio indicates the drainage network of the watersheds is highly affected and controlled by structural geology leading to elongated shape (Tables 1 and 2).

Table 1. Summary of drainage basin linear aspects parameters in the study area

\begin{tabular}{|c|c|c|c|c|c|c|}
\hline Watershed & $\begin{array}{l}\text { Stream } \\
\text { Orders }\end{array}$ & $\begin{array}{l}\text { Stream } \\
\text { Number }\end{array}$ & $\begin{array}{c}\text { Stream } \\
\text { Length }(\mathrm{km})\end{array}$ & $\begin{array}{l}\text { Mean Stream } \\
\text { Order (Lsm) }\end{array}$ & $\begin{array}{c}\text { Stream length } \\
\text { Ratio (RL) }\end{array}$ & $\begin{array}{l}\text { Bifurcation } \\
\text { Ratio (Rb) }\end{array}$ \\
\hline \multirow{8}{*}{  } & $1^{\text {st }}$ & 4529 & 489.4 & 0.11 & 0.62 & 2 \\
\hline & $2^{\text {nd }}$ & 2263 & 304.4 & 0.14 & 0.42 & 2.14 \\
\hline & $3^{\text {rd }}$ & 1056 & 128.2 & 0.12 & 0.6 & 1.52 \\
\hline & $4^{\text {th }}$ & 697 & 76.6 & 0.11 & 0.35 & 2.81 \\
\hline & $5^{\text {th }}$ & 248 & 27.21 & 0.11 & 0.73 & 1.1 \\
\hline & $6^{\text {th }}$ & 225 & 20.0 & 0.09 & 0.36 & 225 \\
\hline & $7^{\text {th }}$ & 1 & 7.2 & $\ldots .$. & $\ldots$. & $\ldots$. \\
\hline & Total & 9019 & 748.5 & & & \\
\hline \multirow{7}{*}{ 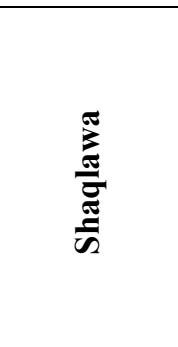 } & $1^{\text {st }}$ & 3324 & 317.6 & 0.09 & 0.57 & 2.21 \\
\hline & $2^{\text {nd }}$ & 1506 & 181.8 & 0.12 & 0.44 & 2.17 \\
\hline & $3^{\text {rd }}$ & 695 & 81.0 & 0.12 & 0.33 & 3.12 \\
\hline & $4^{\text {th }}$ & 223 & 27.1 & 0.12 & 0.29 & 5.44 \\
\hline & $5^{\text {th }}$ & 41 & 7.9 & 0.19 & 4.3 & 41 \\
\hline & $6^{\text {th }}$ & 1 & 33.9 & $\ldots \ldots$ & $\ldots \ldots$ & $\ldots \ldots$ \\
\hline & Total & 5790 & 649.2 & & & \\
\hline
\end{tabular}




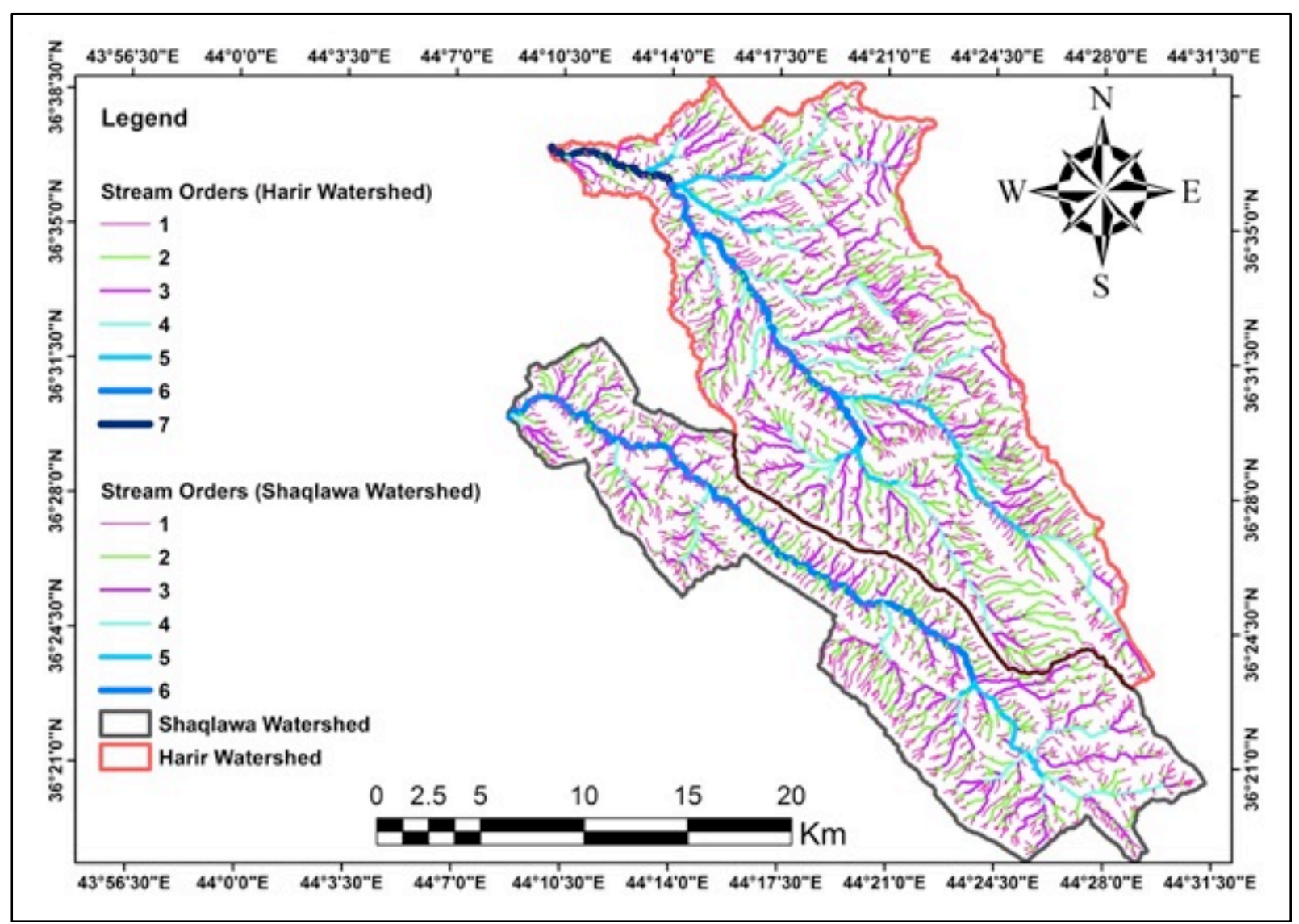

Fig. 3. Stream order distribution map of the studied watersheds

Table 2. Summary of drainage basin linear aspects parameters in the study area

\begin{tabular}{|c|c|c|c|c|}
\hline No. & $\begin{array}{l}\text { Morphometric } \\
\text { parameters (Linear aspects) }\end{array}$ & $\begin{array}{l}\text { Value of the } \\
\text { Harrir watershed }\end{array}$ & $\begin{array}{l}\text { Value of the } \\
\text { Shaqlawa watershed }\end{array}$ & Unit \\
\hline 1. & Basin Length (Lb) & 36.6 & 28.3 & $\mathrm{Km}$ \\
\hline 2. & Perimeter $(\mathrm{P})$ & 111.5 & 105.1 & $\mathrm{Km}$ \\
\hline 3. & Stream Order & see Table 1 & See Table 1 & \\
\hline 4. & Stream Number $(\mathrm{Nu})$ & see Table 1 & see Table 1 & $\ldots \ldots \ldots$ \\
\hline 5. & Stream Length (Lu) & see Table 1 & see Table 1 & $\mathrm{Km}$ \\
\hline 6. & Mean Stream Length (MLu) & see Table 1 & see Table 1 & $\mathrm{Km}$ \\
\hline 7. & Stream Length Ratio (RLu) & see Table 1 & see Table 1 & \\
\hline 8. & Bifurcation Ratio $(\mathrm{Rb})$ & see Table 1 & see Table 1 & $\ldots \ldots \ldots$ \\
\hline 9. & Mean Bifurcation Ratio (MRb) & 39.095 & 10.788 & n....... \\
\hline
\end{tabular}

The area of Harrir and Shaqlawa watersheds is of about $350 \mathrm{~km}^{2}$ and $223 \mathrm{~km}^{2}$, respectively, the stream frequency of watersheds is $25.77 \mathrm{no} . / \mathrm{km}^{2}$ and $25.96 \mathrm{no} . / \mathrm{km}^{2}$ for Harrir and Shaqlawa watersheds, respectively. This means high relief and low permeable rocks in the watersheds. Moreover, the value of drainage density is $3.01 \mathrm{~km} / \mathrm{km}^{2}$ and 2.91 $\mathrm{km} / \mathrm{km}^{2}$ for Harrir and Shaqlawa watersheds, respectively. Both watersheds have moderate drainage density, which indicates the occurrence of moderate to high altitude relief and low 
permeable material in the watersheds. It shows that stream frequency has a direct relationship with drainage density (Table 3). The spatial analyst tool of ArcGIS 10.4 software has been used for calculating and mapping the drainage density of the studied basins (Fig. 4).

Table 3. Summary of drainage basin Areal aspects parameters in the study area

\begin{tabular}{|l|l|l|l|l|}
\hline No. & $\begin{array}{l}\text { Morphometric } \\
\text { parameters (Areal aspects) }\end{array}$ & $\begin{array}{l}\text { Value of the } \\
\text { Harrir watershed }\end{array}$ & $\begin{array}{l}\text { Value of the } \\
\text { Shaqlawa watershed }\end{array}$ & Unit \\
\hline 1. & Basin Area (A) & 350 & 223 & $\mathrm{Km}^{2}$ \\
\hline 2. & Stream Frequency $(\mathrm{Sf})$ & 25.77 & 25.96 & $\mathrm{no} . / \mathrm{Km}^{2}$ \\
\hline 3. & Drainage Density $(\mathrm{D} d)$ & 3.01 & 2.91 & $\mathrm{No}^{-1} \mathrm{~km}^{-1}$ \\
\hline 4. & Drainage Texture (Dt) & 80.89 & 55.09 & $\mathrm{No.} \mathrm{km}^{-3}$ \\
\hline 5. & Elongation Ratio (Re) & 0.58 & 0.60 & $\ldots \ldots \ldots$ \\
\hline 6. & Circularity Ratio (Rc) & 0.35 & 0.25 & $\ldots \ldots \ldots$ \\
\hline 7. & Form Factor (Ff) & 0.26 & 0.28 & $\ldots \ldots \ldots$ \\
\hline 8. & Constant of Channel Maintenance (C) & 0.33 & 0.34 & $\mathrm{Km}$ \\
\hline 9. & Length of Overland Flow (Lg) & 0.16 & 0.17 & $\mathrm{Km}$ \\
\hline
\end{tabular}

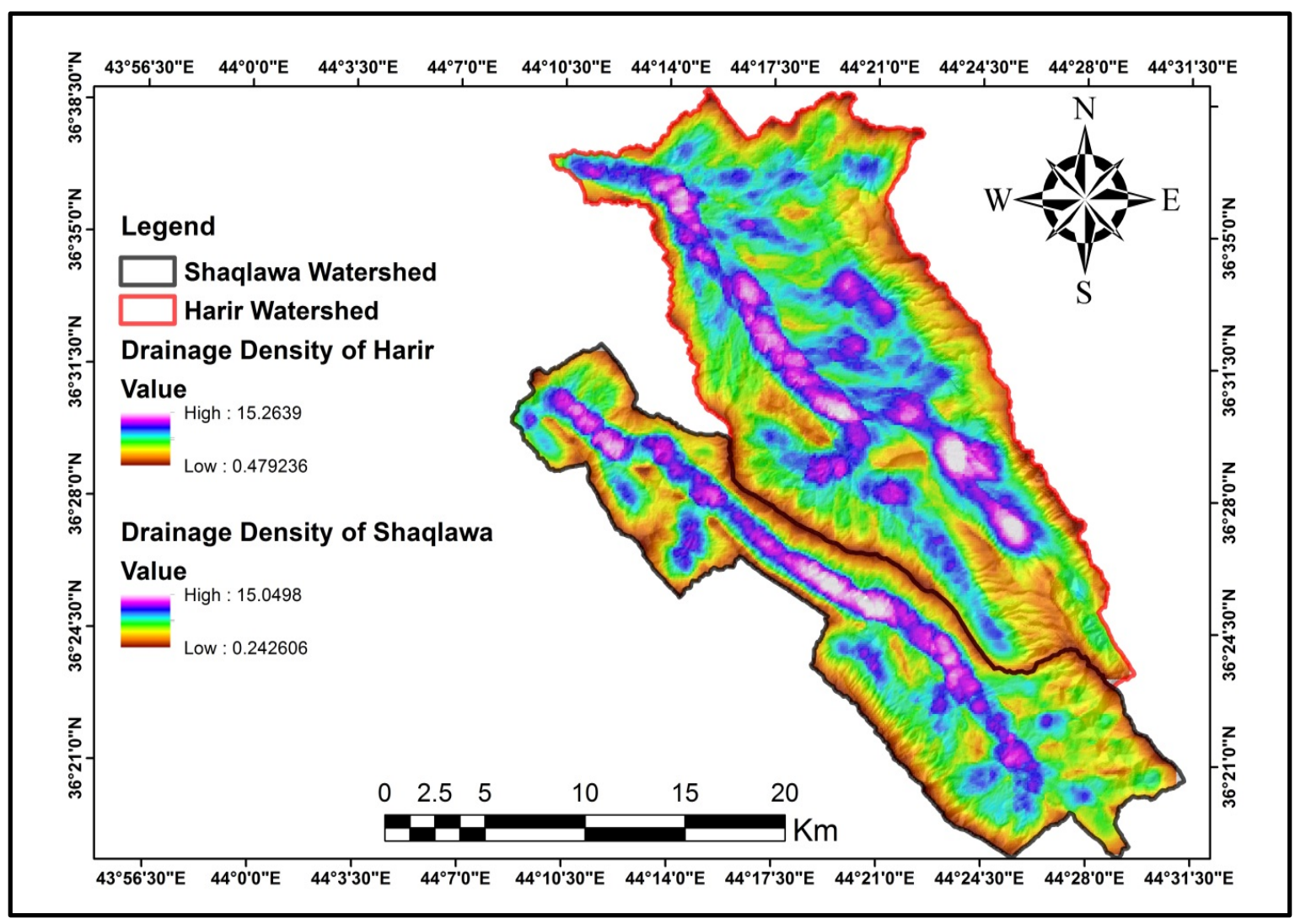

Fig. 4. Drainage density interpolation map for the watersheds in the study area

It has been shown that the studied watersheds belong to very fine drainage texture due to their values 80.89 No. $\mathrm{km}^{-3}$ of Harrir watershed and 55.09 No. $\mathrm{km}^{-3}$ of Shaqlawa watershed. The values of elongation ratio range from 0.58 and 0.6 in the studied Harir and Shaqlawa watersheds, respectively. Values of elongation ratio less than 0.5 indicate more 
elongated watershed, elongated watershed ( 0.5 to 0.7$)$ and the increased value of this ratio to 1 means the shape of the basin becomes circular (Schumm, 1956). The circularity ratio value of Harrir watershed is 0.35 and that of Shaqlawa watershed is 0.25 , this means both watersheds in the study area have an elongated shape which is indicative of the low permeable material and moderate slope in the selected watersheds. The form factor's value of the studied watersheds is low (0.26 and 0.28 for Harrir and Shaqlawa watersheds, respectively), which means that the watersheds have low peak flow with longer time and elongated shape of the watersheds. The length of the overland flow value of Harrir and Shaqlawa watersheds is $0.16 \mathrm{~km}$ and $0.17 \mathrm{~km}$, respectively (Table 3). The low value of the constant of channel maintenance has been obtained for the selected watersheds $(0.33$ and 0.34), which means that the watersheds have formed due to structural geology disturbance, and indicative for low runoff, low permeable rocks and moderate slope. The result shows that the watersheds are characterized by a moderate slope due to high value of the relief ratio. The value of relief ratio of Harrir and Shaqlawa watersheds is 0.04 and 0.05 , respectively, the low values of this ratio for watersheds are due to low permeable material of study area, and the relief of the Harrir watershed is $1457 \mathrm{~m}$ and the Shaqlawa watershed is $1470 \mathrm{~m}$. Moreover, dissection index values of the watersheds are ( 0.79 for Harrir and 0.75 for Shaqlawa). The value of the ruggedness number is 4.39 for Harrir watershed and 4.28 for Shaqlawa watershed (Table 4).

Table 4. Summary of drainage basin Relief aspects parameters in the study area

\begin{tabular}{|l|l|l|l|l|}
\hline No. & $\begin{array}{l}\text { Morphometric } \\
\text { parameters (Relief aspects) }\end{array}$ & $\begin{array}{l}\text { Value of the } \\
\text { Harrir watershed }\end{array}$ & $\begin{array}{l}\text { Value of the } \\
\text { Shaqlawa watershed }\end{array}$ & Unit \\
\hline 1. & Basin Relief (Rb) & 1457 & 1470 & $\mathrm{M}$ \\
\hline 2. & Relief Ratio (Rr) & 0.04 & 0.05 & $\ldots \ldots \ldots$ \\
\hline 3. & Dissection Index (Di) & 0.79 & 0.75 & $\ldots \ldots \ldots$ \\
\hline 4. & Ruggedness Number (Rn) & 4.39 & 4.28 & $\ldots \ldots \ldots$ \\
\hline
\end{tabular}

The drainage pattern of the selected watersheds is mainly dendritic to sub-dendritic and sub-dendritic to sub-parallel types for Harrir and Shaqlawa watersheds, respectively and moderate to steep slope in both watersheds. Generally, stream number and the total length of the stream parameters have strong inverse proportion with the stream order with $\mathrm{R}^{2}=0.78$ and 0.81 for Harrir watershed, respectively (Fig. 5) and $\mathrm{R}^{2}=0.8$ and 0.79 for Shaqlawa watershed correspondingly (Fig. 6). The relations between stream length ratio with stream orders' values have weak proportion; with $\mathrm{R}^{2}=0.044$ and 0.43 for Harrir and Shaqlawa watersheds, respectively (Fig. 7). 


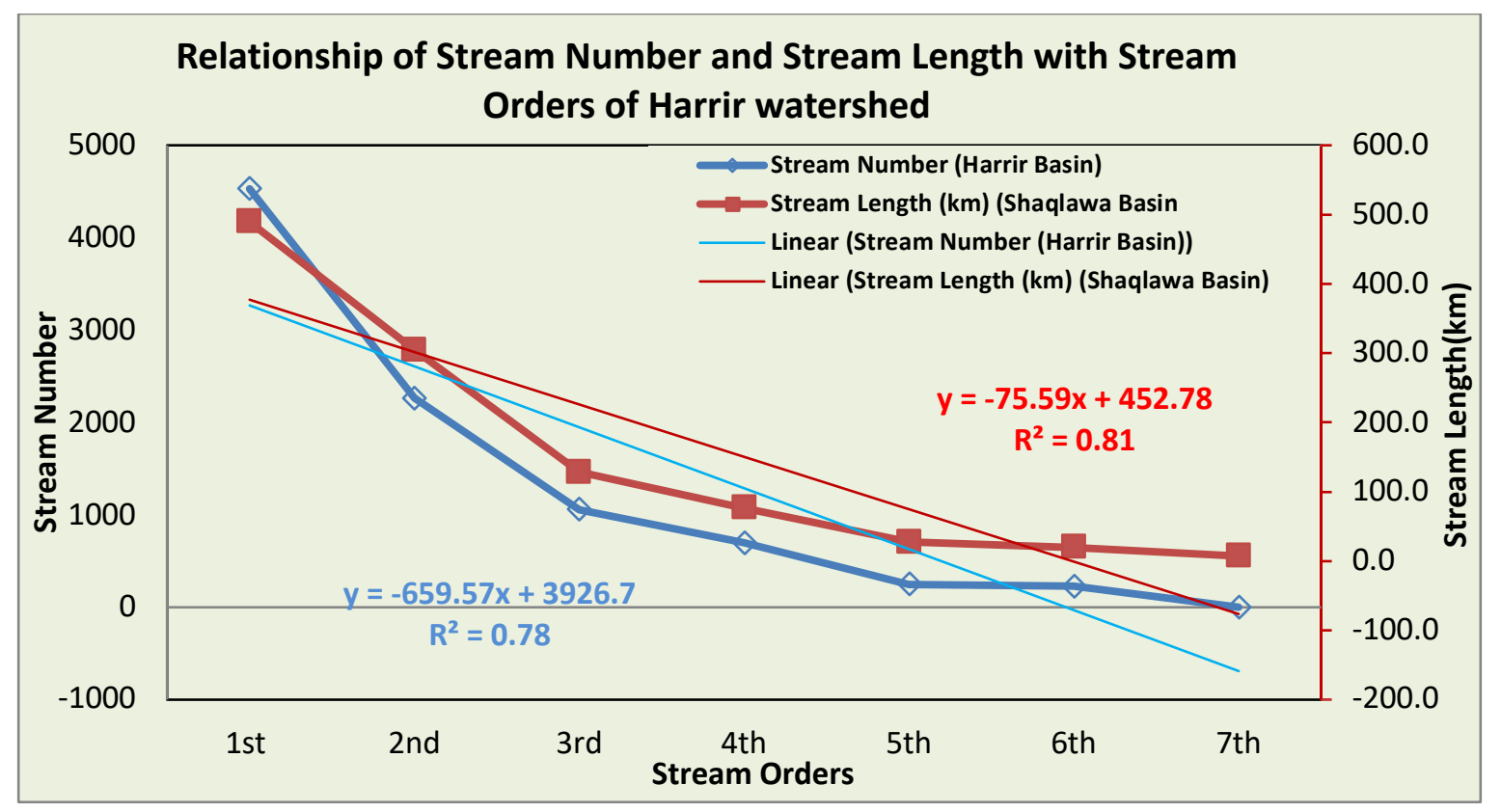

Fig. 5. Relationship of a stream number and stream length values with stream orders values of the Harrir watershed

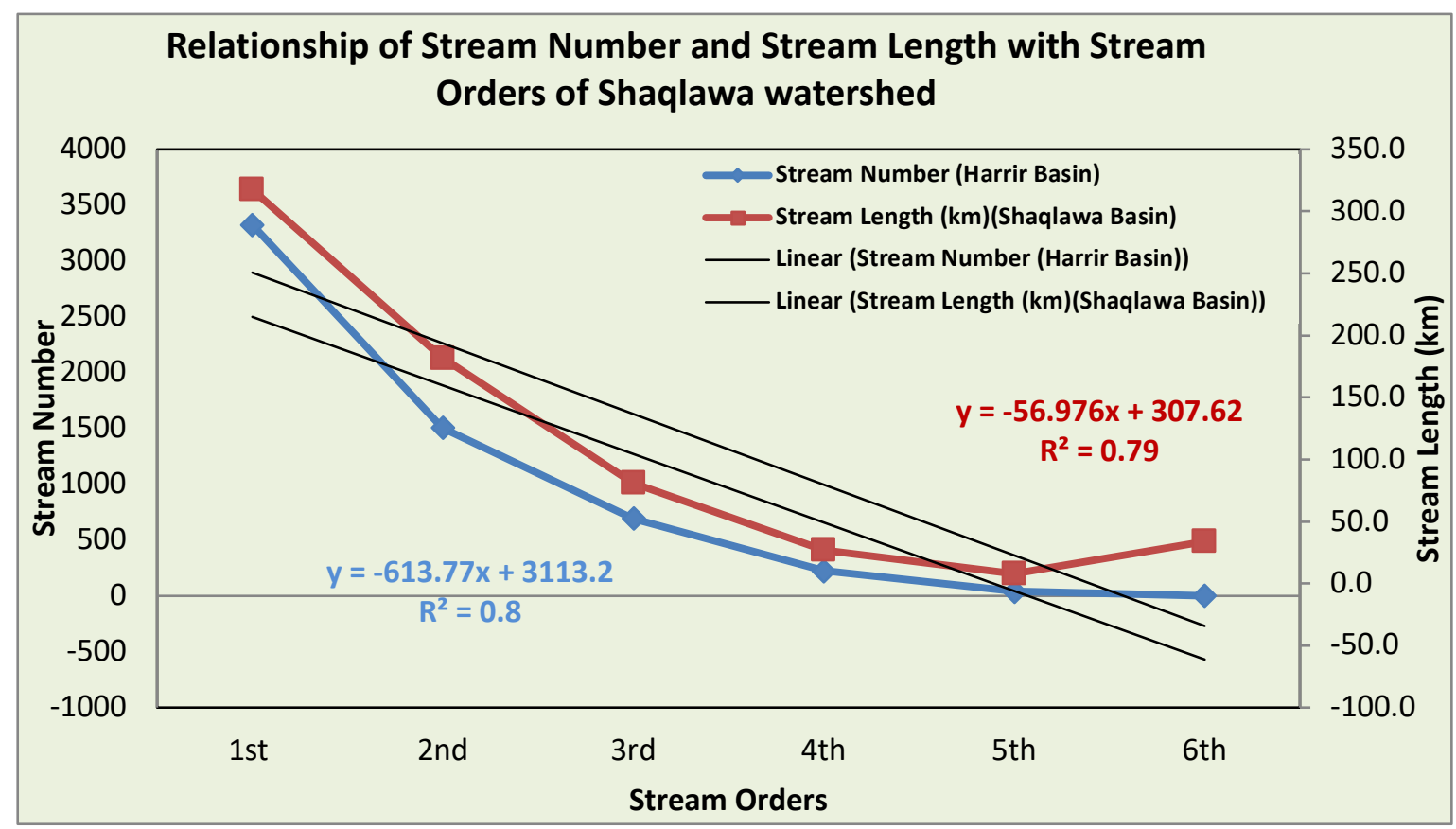

Fig. 6. Relationship of a stream number and stream length values with stream orders values of the Shaqlawa watershed 


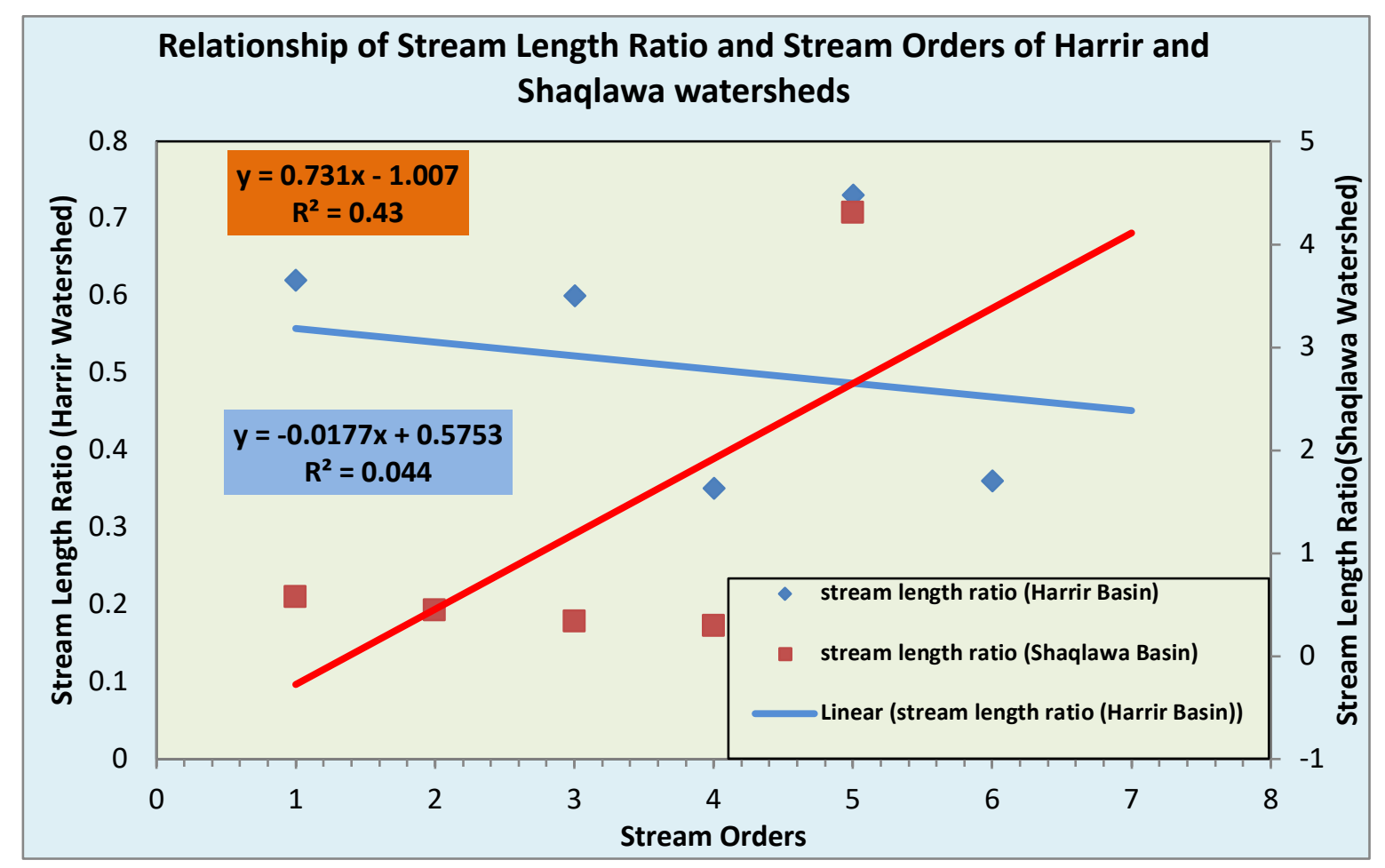

Fig. 7. Relationship of stream length ratio with stream orders values of the Harrir and Shaqlawa watersheds

\section{CONCLUSIONS}

In the present study, remote sensing integrated to GIS methods has been effectively utilized for analyzing the morphometry of two watersheds in the study area. The drainage pattern of the Harrir watershed is dendritic to sub dendritic type with $7^{\text {th }}$ stream order, whereas at the Shaqlawa watershed is sub dendritic to parallel drainage type with $6^{\text {th }}$ stream order. The morphometric parameters in terms of linear, aerial and relief aspects have been used for morphometric analysis. The stream number and stream length values are inversely proportional to stream order's values in the two watersheds of the study area. The results proved that variations of the stream length ratio indicate variations of the slope and landscape of the two watersheds.

The average bifurcation ratio of the studied two watersheds is high, which is an indication for the structural influence on the development of the drainage systems in the watersheds. The two watersheds in the study area have elongated shape due to circularity and elongation ratios, which were studied to determine the importance of watersheds for water management and rainfall harvesting in the area. Additionally, it was revealed that the watersheds are characterized as low permeable material, moderate slope, structurally controlled and low run off which are indicated by high stream frequency, moderate drainage 
density value, very fine drainage texture and dissection index of the watersheds. The study results also showed that the watersheds have moderate slope for flow from the source to the entrance of the watersheds by studying relief aspects. Therefore, it has concluded that using remote sensing data with GIS methods is very significant as effective tools for morphometric analysis which help to understand the development of the watersheds and compare the watersheds, natural resource and water management and detecting flood hazards risk.

\section{ACKNOWLEDGMENTS}

This work was supported by the Kurdistan Ministry of Higher Education and Scientific Research, Salahaddin University-Erbil, Iraq. The authors are very grateful to the editor in chief Prof. Dr. Salih M. Awadh, the secretary of Journal Mr. Samir R. Hijab. and head of the technical editors Dr. Heba S. Al-Mimar for their great efforts and valuable comments.

\section{REFERENCES}

Ali, S. A., and Khan, N., 2013. Evaluation of morphometric parameters - a remote sensing and GIS based approach.

Al-Qayim, B. A., and Ahmed, L. H., 2015. Gis-based geomorphological analysis of Dewana Basin, Sulaimaniyah, Kurdistan, Iraq. Iraqi Bulletin of Geology and Mining, 11(3): 61-82.

Al-Saedi, Z. J., and Al-Obaidi, M. R., 2018. Morphotectonic analysis of Euphrates River Basin, Iraq. Journal of University of Babylon for Pure and Applied Sciences, 26(8): 217-229.

Arabameri, A., Pradhan, B., Pourghasemi, H. R., and Rezaei, K. 2018. Identification of erosion-prone areas using different multi-criteria decision-making techniques and GIS. Geomatics, Natural Hazards and Risk, 9(1), 1129-1155.

Aravinda, P. T., and Balakrishna, H. B., 2013. Morphometric analysis of vrishabhavathi watershed using remote sensing and GIS. International Journal Resource, Eng. Tech, 2(8): 514-522.

Aziz, N. A., Abdulrazzaq, Z. T., and Mansur, M. N., 2020. Gis-based watershed morphometric analysis using dem data in Diyala river, Iraq. Iraqi geological journal, 53(C): 36-49.

Horton, R. E., 1932. Drainage-basin characteristics. Eos, Transactions Am. Geophysics Union, 13(1): 350-361.

Horton, R. E., 1945. Erosional development of streams and their drainage basins; hydrophysical approach to quantitative morphology. Geological Society of America bulletin, 56(3): 275-370.

Kumar, N., 2013. Morphometric analysis of river catchments using remote sensing and GIS (a case study of the Sukri River, Rajasthan). International Journal of Scientific and Research Publications, 3(6): 1-6.

Miller, V. C. 1953. Quantitative geomorphic study of drainage basin characteristics in the Clinch Mountain area, Virginia and Tennessee. Technical report (Columbia University. Department of Geology); no. 3.

Omar, A. A., and Syan, S. H., 2017. Construction of a structural model for Harir anticline within Zagros FoldThrust belt, Kurdistan of Iraq. ZANCO Journal of Pure and Applied Sciences, 28(6): 90-105.

Pareta, K., and Pareta, U., 2011. Quantitative morphometric analysis of a watershed of Yamuna basin, India using ASTER (DEM) data and GIS. International journal of Geomatics and Geosciences, 2(1): 248-269.

Rawat, U., Awasthi, A., Gupta, D. S., Paul, R. S., and Tripathi, T., 2017. Morphometric analysis using remote sensing and GIS techniques in the Bagain River Basin, Bundelkhand Region, India. Indian Journal Science, Technol, 10(10).

Sakthivel, R., Raj, N. J., Sivasankar, V., Akhila, P., and Omine, K. 2019. Geo-spatial technique-based approach on drainage morphometric analysis at Kalrayan Hills, Tamil Nadu, India. Applied Water Science, 9(1): 24.

Schumm, S. A. 1956. Evolution of drainage systems and slopes in badlands at Perth Amboy, New Jersey. Geological society of America bulletin, 67(5): 597-646. 
Seeyan, S., and Merkel, B., 2015. Groundwater modeling of Harrir plain and Mirawa valley in Shaqlawa-Harrir basins, Kurdistan Region, Iraq. Freiberg Online Geology, 39:45-64

Sissakian, V. K., and Fouad, S. F., 2014. Geological Map of Erbil and Mahabad Quadrangle, $2^{\text {rd }}$ edition, scale 1: 1250000. Iraq Geological Survey Publications, Baghdad, Iraq.

Strahler, A. N., 1964. Handbook of applied hydrology. In: Chow VT, editor. Quantitative geomorphology of drainage basins and channel networks. NY: Mc-Graw Hill Book Company, New York.

Veeranna, J., Gouthami, K., Yadav, P. B., and Mallikarjuna, V. R., 2017. Calculating linear and areal and relief aspect parameters using Geo-Spatial Techniques (ArcGIS 10.2 and SWAT model) for Akkeru River Basin Warangal. International Journal of Current Microbiology and Applied Sciences, 6(10):1803-1809.

Zebari, M. M., and Burberry, C. M. 2015. 4-D evolution of anticlines and implications for hydrocarbon exploration within the Zagros Fold-Thrust Belt, Kurdistan Region, Iraq. GeoArabia, 20(1): 161-188. 